\title{
触 New Disease Reports \\ New report of Lolium multiflorum and Rumex crispus as weed hosts of epiphytic populations of Pseudomonas sp., causal agent of yellow bud in onions in Georgia, USA
}

\author{
B. Dutta ${ }^{1}$, R. Gitaitis ${ }^{1}$, K.J. Lewis ${ }^{1}$, C. Booth ${ }^{1}$, D. Langston ${ }^{1}$, T.M. Webster ${ }^{2}$, C.M. Riner ${ }^{3}$ and J.D. Edenfield ${ }^{4}$ \\ ${ }^{1}$ Department of Plant Pathology, University of Georgia, Tifton, GA 31793; ${ }^{2}$ Weed Scientist, Crop Protection and \\ Management Research Unit, USDA-ARS, Tifton, GA-31793; ${ }^{3}$ Tatnall County Extension Coordinator, Reidsville, GA 30453; 4 \\ Toombs County Extension Coordinator, Lyons, GA 30436 \\ *E-mail: bhabesh@uga.edu
}

Received: 05 Oct 2012. Published: 18 May 2013.

Yellow bud, an emerging bacterial disease of onion (Allium cepa), has been spreading throughout the Vidalia onion-growing region in Georgia, USA since 2007 (Gitaitis, 2012). Symptoms of yellow bud include intense chlorosis in emerging leaves and severe blight in the older leaves leading to stand loss and reduced bulb size. The causal agent is a Gram-negative, ice-nucleating, rod-shaped, non-fluorescent, aerobic bacterium. The bacterium possesses all the phenotypic characteristics of Pseudomonas syringae van Hall LOPAT group Ia of Lelliott et al. (1966) as it produces levan, is negative for oxidase, potato rot, and arginine dihydrolase and produces a hypersensitive reaction in tobacco. Like some other species sharing these traits, yellow bud strains have the ability to produce the toxin coronatine. In the spring of 2012, weed samples (20 samples at each location) were collected from the edge of fields in three different counties (one fallow field where yellow bud was first observed in 2007 and two fields with onions currently expressing yellow bud symptoms). Samples were placed in $25 \mathrm{ml}$ of phosphate-buffered saline and shaken overnight at $24^{\circ} \mathrm{C}$. After incubation, $4.0 \mathrm{ml}$ aliquots were removed and divided into two fractions $(3.0 \mathrm{ml}$ and $1.0 \mathrm{ml})$ that were placed in separate, sterile micro-centrifuge tubes. Total genomic DNA was isolated from the $3.0 \mathrm{ml}$ fraction using commercial extraction kits and subjected to SYBR green-real-time PCR using primers that amplify the coronafacate ligase (cfl) gene (Gitaitis et al., 2012). The remaining $1.0 \mathrm{ml}$ fraction was spread-plated on nutrient agar (NA) supplemented with $0.5 \%$ yeast extract (NA+).

The PCR assay detected the bacterium on Italian ryegrass (Lolium multiflorum) from all three locations and on curly dock (Rumex crispus) from only the fallow field. Bacterial colonies isolated on NA+ had characteristics similar to previously reported yellow bud strains (Lelliot $e t$ al., 1966). When 15-day old onion seedlings, cv. Century, (= 10/strain/experiment) were inoculated with a suspension of $1 \times 10^{8} \mathrm{cfu} / \mathrm{ml}$ (using a hypodermic needle, with $1 \mathrm{ml}$ of inoculum injected into the cavity of onion leaf), $100 \%$ of the seedlings developed yellow bud symptoms 14 days after planting under greenhouse conditions $\left(\sim 24^{\circ} \mathrm{C}\right.$ and $\left.\sim 50 \% \mathrm{RH}\right)$. Ten control plants inoculated with sterile water remained healthy.
Bacterial colonies were re-isolated from seedlings showing symptoms. The non-fluorescent colonies recovered had similar characteristics to those described above. Universal primers fD1 and rD1 (Weisberg et al., 1991) and cfl1 (GGCGCTCCCTCGCACTT) and cfl2 (GGTATTGGCGGGGGTGC) were used to amplify the 16S rRNA and coronafacate ligasegenes, respectively. Amplified products were sequenced and BLAST searched in GenBank. The nucleotide sequences of the weed strains (GenBank Accession Nos. KC786974 to KC786977) matched Pseudomonas sp.7Y-1 (JF939842.1; Gitaitis, 2012) and P. syringae pv. atropurpurea (AB001440.1) (97 to 98\% similarity with $16 \mathrm{~S}$ rRNA and 94 to $98 \%$ by coronafacate ligase gene). Inoculation of isolated strains on four-week old Italian ryegrass and curly dock seedlings under greenhouse conditions (both by injecting $1 \mathrm{ml}$ of inoculum at $1 \times 10^{8}$ $\mathrm{cfu} / \mathrm{ml}$ into the leaf blade or by spraying at the same inoculum concentration on the leaf surface until runoff) did not result in yellow bud symptoms, when incubated for 28 days. Our data suggest that these bacteria survive as epiphytes without inciting any symptoms on their weed hosts. However, they possess ability to cause disease on inoculated onion seedlings. Understanding the epidemiology of yellow bud should be helpful for developing disease management strategies.

\section{References}

Gitaitis RD, Mullis S, Lewis K, Langston D, Watson AK, Sanders H, Torrance R, Jones JB, Nischwitz C, 2012. First report of a new disease of onion in Georgia caused by a non-fluorescent Pseudomonas species. Plant Disease 96, 285. [http://dx.doi.org/10.1094/PDIS-05-11-0400]

Lelliot RA, Billing E, Hayward AC, 1966. A determinative scheme for the fluorescent plant pathogenic pseudomonads. Journal of Applied Bacteriology 29, 470-489.

[http://dx.doi.org/10.1111/j.1365-2672.1966.tb03499.x]

Weisburg WG, Barns SM, Pelletier DA, Jane DJ, 1991. 16S ribosomal DNA amplification for phylogenetic study. Journal of Bacteriology $\mathbf{1 7 3}$, 697-703.

To cite this report: Dutta B, Gitaitis R, Lewis KJ, Booth C, Langston D, Webster TM, Riner CM, Edenfield JD, 2013. New report of Lolium multiflorum and Rumex crispus as weed hosts of epiphytic populations of Pseudomonas sp., causal agent of yellow bud in onions in Georgia, USA. New Disease Reports 27, 18. [http://dx.doi.org/10.5197/j.2044-0588.2013.027.018] 